\title{
EVALUATING THE POSSIBILITY OF RECYCLING BANANA WASTE AS A FEED FOR RUMINANTS: \\ I- CHEMICAL COMPOSITION, RUMEN-LIQUOR PARAMETERS, DIGESTIBILITY COEFFICIENTS, AND FEEING VALUES BY LAMBS
}

\author{
Abdelhamid, A. M.*; G. H. A. Ghanem ${ }^{\star *}$; A. M. Aiad ${ }^{\star \star}$ and \\ R. I. M. Matari** \\ *Faculty of Agriculture, Al-Mansourah University \\ ${ }^{\star *}$ Animal Production Res. Institute, Agric. Res. Center, Egypt.
}

\begin{abstract}
Three underground trenches with the capacity of 6 tons ( 2 tons each) were used for making silage from banana wastes. Rice straw was added to banana wastes at the rate of $1: 2$, while molasses was added at the rate of $5 \%$. The first kind of silage $\left(T_{2}\right)$ was made without any additive. In the second silage $\left(T_{3}\right)$, urea was added at the rate of $3 \%$, while in the third silage $\left(\mathrm{T}_{4}\right), \mathrm{EM}_{1}$ (biological treatment) was added at the rate of $1 \%$. Whereas $T_{1}$ was a control. The rations were fed ad libitum of silage, while concentrate feed mixture consisted $70 \%$ from the requirements. Twenty lambs (crossbreed Finnish rams, Finnish $x$ Rahmani) having 4 months of age and averaging $22 \pm 0.5 \mathrm{~kg}$ live body weight were used in this experiment. Lambs were divided into four similar groups according to their live body weight (5 animals in each). The results of this study revealed that banana waste silage with urea before ensiling increased $\mathrm{CP}$ and ash, but limited increased CF and EE, and decreased contents of OM and NFE. Making silage decreased CF and EE, but increased CP, NFE, and ash in BWES. Addition of urea and effective microorganism affected silage. Ruminal pH values decreased at 3 hours after feeding $\left(5.73 \mathrm{~T}_{1}, 5.9 \mathrm{~T}_{2}, 6.47 \mathrm{~T}_{3}\right.$ and $\left.5.8 \mathrm{~T}_{4}\right)$. The treatment with urea increased $\mathrm{pH}$ values compared to other treatment. The highest level of ammonia- $\mathrm{N}$ concentration $\left(\mathrm{mg} / 100 \mathrm{ml}\right.$ ) produced in rumen was $\left(16.42 \mathrm{~T}_{3}\right)$ compared with $T_{2}(15.64)$ and $T_{4}(14.86)$. These levels decreased after 6 hours of feeding, being $T_{1}$ (13.25), $T_{2}$ (10.17), $T_{3}$ (12.51) and $T_{4}$ (9.38). The concentration of volatile fatty acids 3 hours after feeding was the highest in $T_{3}$ and $T_{4}(13.82$ and 11.68 meq, respectively). At 6 hours after feeding, TVFA's tended to increase in $T_{3}$ and $T_{4}$ compared to $\mathrm{T}_{2}(16.00,12.00$ and $10.17 \mathrm{meq}$, respectively). Digestibility coefficients of DM increased significantly in $T_{4}$ and $T_{3}$ compared to $T_{2}(67.10,65.91$ and $63.16 \%$, respectively. Digestibility coefficients of $O M$ increased significantly in $T_{4}$ \& $T_{3}$ compared to $\mathrm{T}_{2}(68.11,66.89$ and $64.10 \%$, respectively). Digestibility coefficients of $\mathrm{CP}, \mathrm{CF}, \mathrm{EE}$ and NFE increased significantly in $\mathrm{T}_{4}$ and $\mathrm{T}_{3}$ compared to $\mathrm{T}_{2}$, being 64.58 $66,66 \& 87 \% ; 56.91,55.33$ \& 52.39\%; 82.14, 81.53 \& 78.28\%; and 70.95, 68.16, $65.03 \%$, respectively. These data indicated good silage of $T_{4}$ compared to $T_{2}$. $T_{4}$ contained more DM, OM, CP, CF, EE and NFE $(67.10,68.11,64.58,56.91,82.14$ and $70.15 \%$, respectively), compared to $\mathrm{T}_{1}$ (DM, OM, CP, CF, EE and NFE being 70.47 , $71.52,68.44,53.94,8.81$ and $74.52 \%$, respectively). No significant differences between $T_{3} \& T_{4}$ were found, except for CF. Significant differences were found between $T_{1}, T_{4}$ and $T_{2}$ compared to $T_{3} \& T_{4}$. The nutritive value as TDN increased insignificantly between $T_{3}$ and $T_{4}(63.29$ and $64.98 \%)$ but increased significant between $\mathrm{T}_{3} \& \mathrm{~T}_{4}$ compared to $\mathrm{T}_{2}(63.29,64.98$ and $60.11 \%$, respectively). There were significant decreases in TDN of $\mathrm{T}_{2}, \mathrm{~T}_{3} \& \mathrm{~T}_{4}$ compared to $\mathrm{T}_{1}(60.11,63.29,64.98$ and $67.77 \%$, respectively). The nutritive value as DCP differed insignificantly between $\mathrm{T}_{3} \&$ $\mathrm{T}_{4}$ (10.46 and $10.18 \%$, respectively), but both $\left(\mathrm{T}_{3}\right.$ and $\mathrm{T}_{4}$ ) increased significantly
\end{abstract}


compared to $\mathrm{T}_{2}(10.46,10.18$ and $9.52 \%$, respectively). Significant decreases were found between $T_{2}, T_{3}$ and $T_{4}$ compared to $T_{1}(9.52,10.46,10.18$ and $11.15 \%$ DCP, respectively). From the foregoing results it could be concluded that $\mathrm{EM}_{1}$ as an additive for making silage of banana waste was effective. Ensilage of banana wastes with urea or $\mathrm{EM}_{1}$ reduced the tannins level and CF content but increased OM, CP, NFE and nutritive value; as well as nutrients digestibility comparing with the banana waste silage without additives, (even comparing with the control, e.g. for CF and EE). So, it is to recommend using banana waste silage with $\mathrm{EM}_{1}$ (or urea) in feeding ruminants.

Keywords: Banana waste, Silage quality, Chemical composition, Rumen liquor, Digestibility coefficients, Feeding values, Lambs.

\section{INTRODUCTION}

In Egypt, animal feed resources are limited which do not allow increasing livestock population to a level satisfies human demands. Moreover, feed shortage is also unevenly divided between summer and winter. Where in winter season; berseem is the major forage crop covering 45.91 and $124.52 \%$ of yearly animal requirements of energy and protein, respectively (Abou-Selim and Bendary, 2005). While in summer season, the available feeds are mainly concentrates and straws which cover $39 \%$ and $22 \%$ of the local animal requirements of energy and protein, respectively (EISerafy, 1991). Encouraging results obtained confirm that using crops wastes in animal diets could participate in reducing the shortages of animal feeds and subsequently increase milk and meat production. Many efforts have been carried out to evaluate available waste products for feeding animals (Abdelhamid, 1988). Banana leaves and pseudo stems have chemical analysis close to clover composition and can play an important role to cover some nutrient requirements of the animals (Abd El-Gawad et al., 1994). Highest live weight gain was achieved when diet was supplemented with banana, this suggests that fodder supplement with green banana can improve cattle nutrition in the humid tropics (Ibrahim et al., 2000). Wastes of banana trees are one of the solutions, which may share in solving this problem. The annual cultivated area from banana plants in Egypt is about 39.00 feddans (Ministry of Agriculture and Reclaiming land, 2003). The wet materials (leaves and pseudo stems) are about 40 tons per feddan. The total wet material is about 1.400 .000 tons which is estimated to be about 89.000 tons dry matter. The main shortcoming of banana wastes as sole animal feed lies in their low digestible energy and protein contents and its containing of antinutritional compounds (Tannin). Biological treatments such as white rot fungi (Abdelhamid et al., 2006 \& 2007), as Trichoderma viride (El-Ashry et al., 2003 and Abdelhamid et al., 2009a, b \& c) and Penicillium funiculusms (ElAshry et al., 2003) were used to improve the nutritive value and digestibility of poor quality roughages. Also, yeast treatment was used to improve rumen digestibility of nutrients especially crude fiber, in term of elevation rumen fermentation and more activation of rumen microorganisms (Dawson, 1992). The main objective of this study was to determine the influence of incorporation of different kinds of silage made from banana plant wastes on 
chemical composition, silage quality, rumen fermentation, nutrients digestibility, and nutritive value by ram lambs.

\section{MATERIALS AND METHODS}

This work was carried out at Sakha Animal Production Station, Animal Production Research Institute, Agric. Research Center and Animal Production Department, Faculty of Agriculture, Al-Mansourah University during 2007/2008 for about 26 weeks.

\section{Silage preparation:}

Three under ground trenches with capacity of 6 tons ( 2 ton each) were used for ensiling the fresh banana plant leaves and stems which collected after harvesting immediately from Giza governorate (EI-Waraq), then (banana by-products) were chopped $(20-25 \mathrm{~cm})$ by a hand machine and sun dried for a period of $7-10$ days to reach a moisture content of about $65-70 \%$. The silage was prepared by filling successive layers of the chopped materials and heavily trodden before adding the next layer. However, each layer was consisted of the banana wastes and chopped rice straw (2:1). Molasses was added at the rate of $5 \%$. The first trench had no additives, but urea was added at $3 \%$ (dissolved in water) to the second and microorganisms (EM1) were added at $1 \%$ from weight silage in the third trench. Molasses and urea were purchased from Nobaria Animal Production Station, whereas rice straw and berseem hay were taken from Sakha Animal Production Station.. After filling the trenches with the materials they were pressed well then covered by thin layer of polyethylene sheet $(180 \mu \mathrm{m})$. Soil and straw layers of approximately $20 \mathrm{~cm}$ thickness were covered the polyethylene sheet then tires to get anaerobic conditions for 8 weeks. Effective microorganisms $\left(E_{1}\right)$, from EM research organization (EMRO), Jaban and Ministry of State for Environmental affairs contained photosynthetics bacteria (Rhadopseudomonas plustris and Rhodobacters phacrodes), lactic acid bacteria (Lactobacillus plantaru, Lactobacillus case and Streptococcus lactis), yeasts (Saccharomyces cerevisiae) and Actinonycetes (Microhiza) according to El-Dosyki et al. (2002). For determination of silage quality after 8 weeks, the bunkers were opened and the color and odor were examined directly. Representative samples were taken from each kind of silage material before and after ensiling for chemical analysis and $\mathrm{pH}$ values determination.

\section{Experimental animals and feeding system:}

To study the effect of feeding lambs on the tested three different types of silage on growth performance, twenty crossbred ram lambs (3/8 Finnish Landrace x 5/8 Rahmani) having 4-5 months of age and averaging $22 \pm 0.5$ $\mathrm{kg}$ live body weight were used in this experiment. Lambs were divided into four similar groups according to their live body weight (5 animals in each). Lambs in all groups were fed diets which contained the same amount of concentrate feed mixture (CFM). The dietary treatments were: T1) concentrate feed mixture (CFM) of lactation $(17 \% \mathrm{CP})+$ berseem hay $(\mathrm{BH})$ as a control; T2) CFM + banana waste silage (BWS) without additives (banana waste $2: 1$ rice straw $+5 \%$ molasses); T3) CFM + BWS with urea $3 \%$ 
$+5 \%$ molasses (BWUS); and T4) CFM + BWS with effective microorganisms $1 \%\left(E M_{1}+5 \%\right.$ molasses, BWES). Feeding of all groups was on the basis of $4 \%$ DM of their live body weight, concentrate ratio in diet of all groups was $70 \%$ from NRC (1985) requirement silage ad libitium. Amount of CFM were adjusted biweekly according to the actual live body weight. The experimental feeding period lasted from weaning up to 180 days (about 26 weeks). Freshwater and Calphos Block (from Turkey) were available all times and feeds were offered twice daily at 8 a.m and 4 p.m. Block Bilesimi consisted of $(\mathrm{mg} / \mathrm{Kg}) 20.000 \mathrm{Ca}, 10.000 \mathrm{P}, 30.000 \mathrm{Mg}, 500 \mathrm{Fe}, 40$ Co, $500 \mathrm{Cu}, 100 \mathrm{I}$ 4.000 Mn, 2.5 Zn, $1.000 \mathrm{~S}, 20 \mathrm{Se}, 33.7 \mathrm{Na}, 50.000$ iu vit. A, 10.000 iu vit. D, and 20 vit. E.

Digestibility trials:

At the end of the experimental period three ram lambs weighing about $45 \mathrm{~kg}$ LBW and aging 10 months were taken randomly from each dietary treatment and placed in metabolic cages. Animals in all groups were fed the same diets for a period of 2 weeks as preprimary period followed by 7 days as a collection period. In the digestibility trials, the animals were fed $1000 \mathrm{~g}$ silage and $800 \mathrm{~g}$ concentrate feed mixture. The daily feces excreted were collected and weighed then $10 \%$ of the daily feces were taken and dried for 24 hours at $65^{\circ} \mathrm{C}$ to determine the daily dry matter excreted. Composite fecal samples were taken and stored for chemical analysis. Rumen liquor samples were taken from three animals of each digestibility trial at the end of the collection period of the three digestion trials. Sample from rumen liquor were taken before morning feeding (zero time) and at 3 and 6 hours after morning feeding (post-feeding). Samples were taken using rubber stomach tube. Immediately after rumen liquor collection, ruminal $\mathrm{pH}$ values were measured by $\mathrm{pH}$ meter, then rumen liquor of each animal was strained through four layers of cheese cloth and stored at $-20^{\circ} \mathrm{C}$ until chemical analysis for concentration of total volatile fatty acids (TVFA's) and ammonia- $\mathrm{N}\left(\mathrm{NH}_{3}-\mathrm{N}\right)$. The $\mathrm{pH}$ values were measured as soon as the rumen liquor was collected before adding the preservatives using a $\mathrm{pH}$ meter. Ruminal ammonia- $\mathrm{N}$ was determined according to the procedures outlined by Conway (1957). Total VFA's were determined according to the method of Warner (1964) using Markam micro-distillation apparatus.

Chemical analysis:

Dry matter, crude protein, ether extract, crude fiber and ash of feeds and faces were analyzed according to the methods of A.O.A.C. (1990). Tannins content were determined by the method of A.O.A.C. (1980).

Statistical analysis:

The obtained data were statistically analyzed using general linear models procedure adapted by SPSS (2004) for Windows for user's guide. Least significant differed according to Duncan (1955) within program SPSS was done to determine the degree of significance between means. 


\section{RESULTS AND DISCUSSION}

\section{Chemical composition:}

The chemical composition of fresh banana waste, rice straw, banana waste silage, banana waste urea silage and banana waste $\mathrm{EM}_{1}$ silage (BWF, RS, BWS, BWUS and BWES) is shown in Table (1). The present results showed that BWF had 7.2 DM, 81.46 OM, 7.54 CP, 31.62 CF, 1.22 EE, 41.08 NFE and $18.54 \%$ ash. Data indicated that BWUS contained the highest content of $\mathrm{CP}, \mathrm{EE}$ and ash. It was noticed that the addition of urea before ensiling caused an increase in both $\mathrm{CP}$ and ash and limited increase in CF and EE, while lowest contents of OM and NFE in BWUS may be due to the addition of rice straw and molasses. The obtained results agree with those reported by many authors (Hassan et al., 2005 and Mohsen et al., 2006), who found that chemical composition of banana waste fresh had 7.40 DM, 84.55 OM, 6.36 CP 32.69 CF, 0.78 EE, 44.72 NFE and $15.45 \%$ ash on dry matter basis. It could be seen from Table (2) the chemical composition of CFM, BH, BWS, BWUS and BWES indicated that making silage decreased CF and EE but increased CP and NFE, and ash in BWES. It was noticed that the addition of urea and effective microorganisms improved CP, CF and NFE contents of the silages. The obtained results agree with Mohsen et al. (2006), who found that silage making decreased CF and cell wall components, but increased EE and ash contents. Also, Biomin (2008) mentioned that inoculant led to higher production of lactic acid and therefore lower $\mathrm{pH}$ value, decreased butyric fermentation or inhibition of the clostridia fermentation and a higher recovery of energy in the ensiled matter.

\section{Fermentation characteristics of silages:}

At the end of the fermentation period (8 weeks) and as shown in Table (3), the present results showed that $\mathrm{pH}$ values were $4.25 \mathrm{BWS}, 4.45$ BWUS, and 4.35 BWES. Ammonia-N (\%) of total N was 2.29 BWS, 5.22 BWUS, and 1.4 BWES. Total volatile fatty acids (\% of DM) was 1.53 BWS, 2.14 BWUS, and 1.36 BWES. These results agree with those of Mahmoud (2005), who found that at the end of the fermentation period (6 weeks), $\mathrm{pH}$ values reached 4.3, 4.52 and 4.01 and total VFA concentration reached 2.15, 3.10 and $2.36(\mathrm{mM} / 100 \mathrm{ml})$ for the control, ureated, inoculant silages, respectively. Whereas ammonia- $\mathrm{N}$ concentration reached $16.81(\mathrm{mg} / 100 \mathrm{ml})$ for banana waste silage treated with urea, while that inoculated had 10.88 $(\mathrm{mg} / 100 \mathrm{ml})$ and the control silage had $10.36(\mathrm{mg} / 100 \mathrm{ml})$, which correlated with the $\mathrm{pH}$ values of silage. However, all silages tested were normal colored, moist, odor and solid. The highest acceptable $\mathrm{pH}$ value in silage is 5.0 (Meyer et al., 1980) and up to $8 \%$ ammonia, make the stage good (Abdelhamid, 1991). Additionally, increasing ammonia and $\mathrm{pH}$ value in a silage are indicators for poor quality silage (Flynn, 1988 and Woolford, 2007). Total bacterial count was $5.7 \times 10^{8}$ BWS, $2.9 \times 10^{6}$ BWUS, and $8.3 \times 10^{7}$ (CFU) BWES (Table 3). Aflatoxin examination revealed no aflatoxin was found in silages. Although the normale total bacterial count (Abdelhamid, 1991), urea addition led to lower count followed by EM $\mathrm{M}_{1}$ comparing with BWS. However, the absence of aflatoxins may be due to lower fungal count which 
may be attributed to the presence of urea (Abdelhamid et al. (1994) and microorganisms, and/or low $\mathrm{pH}$ values for the good ensilage conditions. Moreover, Oliveira and Furlong (2008) found that the extract of banana reduced the production of aflatoxin $\mathrm{B}_{1}$. However, Abdelhamid et al. (2001) found aflatoxin $B_{1}$ contamination in silage $(.452 \mathrm{ppb})$ may be for aeration which enable molding and spoilage (Cullison, 1982).

Table (1): Chemical composition of tested feedstuffs before ensiling.

\begin{tabular}{|c|c|c|c|c|c|}
\hline Item & BWF & RS & BWS & BWUS & BWES \\
\hline DM \% & 7.20 & 89.26 & 34.20 & 34.10 & 33.95 \\
\hline \multicolumn{6}{|c|}{ Composition of DM \% } \\
\hline OM & 81.46 & 32.02 & 76.98 & 76.41 & 77.43 \\
\hline CP & 7.54 & 3.23 & 6.59 & 11.38 & 7.70 \\
\hline CF & 31.62 & 33.65 & 32.32 & 32.50 & 32.69 \\
\hline EE & 1.22 & 1.41 & 2.33 & 2.68 & 2.60 \\
\hline NFE & 41.08 & 43.73 & 35.72 & 29.85 & 34.44 \\
\hline Ash & 18.54 & 17.98 & 23.02 & 23.59 & 22.57 \\
\hline
\end{tabular}

BWF: Fresh banana waste,

BWS: Banana waste silage,

RS: Rice straw,

BWES: Banana waste silage with EM

BWUS: Banana waste silage with urea,

Table (2): Chemical composition of feedstuffs of the experimental silages.

\begin{tabular}{|c|c|c|c|c|c|}
\hline Item & CFM & BH & BWS & BWUS & BWES \\
\hline DM \% & 92.15 & 92.40 & 31.90 & 31.80 & 32.70 \\
\hline \multicolumn{7}{|c|}{ Composition of DM \% } \\
\hline OM & 93.24 & 87.86 & 77.19 & 77.80 & 75.37 \\
\hline CP & 17.05 & 14.57 & 7.09 & 9.49 & 8.81 \\
\hline CF & 6.73 & 22.66 & 31.17 & 29.78 & 27.33 \\
\hline EE & 2.95 & 2.10 & 2.82 & 2.27 & 2.15 \\
\hline NFE & 66.51 & 48.53 & 36.11 & 36.26 & 37.08 \\
\hline Ash & 6.76 & 12.14 & 22.81 & 22.20 & 24.63 \\
\hline
\end{tabular}

CFM: Concentrate feed mixture, BH: Berseem hay,

BWS: Banana waste silage, $\quad$ BWUS: Banana waste silage with urea,

BWES: Banana waste silage with $\mathrm{EM}_{1}$

Aflatoxins impair liver and kidney function, delay blood clotting, increase susceptibility to bruising, and interfere with cellular humoral immune system (Diekman and Green, 1992) as well as suppression of cellular immunity (Qureshi et al., 1998). So, inhibition of DNA, RNA and protein synthesis via a variety of different mechanisms appears to be directly or indirectly responsible for the immunosuppressive action of many mycotoxins (Corrier, 1991). Studies have linked human exposure to aflatoxins to increased prevalence of infection (IARC, 2002). Prenatal exposure to aflatoxin produced a delay of early response development, impaired locomotors coordination, and impaired learning ability in the offspring of rats exposed to aflatoxin during middle pregnancy, and the early gestational exposure appears to produce more effects than latter exposure (Kihara et al., 2000). Aflatoxins cross the human placenta. It is associated with growth impairment in young children (IARC, 2002). Its chronic symptoms include 
liver and kidney damage; reduced growth, anemia, bruising and immune suppression (Herman and Trigo- Stockli, 2008). The biochemical effects of aflatoxins included carbohydrate metabolism, lipid metabolism, vitamin assimilation, protein synthesis, mitochondrial respiration, endocrine system, and skeletal system (Verma, 2007) as well as DNA damage (El-Barbary, 2008). Mycotoxins are found frequently in different feedstuffs (Abdelhamid, 1993a,b \& 2009a and Swamy, 2009). And threat not only plant crops, but also animal and human health (Abdelhamid and Saleh, 1996; Abdelhamid, 2004 \& 2005; and Abdelhamid et al., 1999). El-Shanawany et al. (2005) isolated numerous fungal genera (Aspergillus, Penicillium, Fusarium and Gibberella) as well as many mycotoxins, particularly aflatoxins, which showed the highest incidence rates in silage samples from Assiut and Sohag governorates. However, moldy silage is frequently asked questions (Albert Govt., 2008). The mycotoxin problem could be overcome by good farming and nutrition (Abdelhamid, 1995 \& 2000; and Taylor-Pickard, 2008).

Table (3): Fermentation characteristics of different kinds of silages.

\begin{tabular}{|l|c|c|c|}
\hline \multicolumn{1}{|c|}{ Item } & BWS & BWUS & BWES \\
\hline The $\mathrm{pH}$ value & 4.25 & 4.45 & 4.35 \\
\hline Ammonia-N,\% of total N & 2.29 & 5.22 & 1.40 \\
\hline Total volatile fatty acids, \% of DM & 1.53 & 2.14 & 1.36 \\
\hline Total count of microorganisms, cfu/g & $5.7 \times 10^{8}$ & $2.9 \times 10^{6}$ & $8.3 \times 10^{7}$ \\
\hline Aflatoxin, ppb & - & - & - \\
\hline Tannins (g/100 g) before ensiling & 0.90 & 0.95 & 0.91 \\
\hline after ensiling & 0.95 & 0.85 & 0.75 \\
\hline
\end{tabular}

BWS: Banana waste silage,

BWUS: Banana waste silage with urea,

BWES: Banana waste silage with $\mathrm{EM}_{1}$

Tannins tended to decrease after fermentation (Table 3), being 0.90 BWS, 0.95 BWUS, and 0.91\% BWES before ensiling, but became 0.95 BWS, 0.85 BWUS and $0.75 \%$ BWES after ensiling. These results may be due to the addition of urea and effective microorganism. Generally, the results obtained agree with those reported by Viswanathan et al. (1989) that the mean composition of banana stalk of tannin content was only $0.74 \%$ as tannic acid equivalent. These data indicated good silage fermentation, and inoculant with $\mathrm{EM}_{1}$ was proved to be the best silage compared to the other two silages. Anyhow, tannins are frequently found in many forages and agroindustrial wastes and may harm the livestock animals by high consumption as unconventional feed resources (Abdelhamid and El-Ayouty, 1988 and Abdelhamid, 1991, 2003, 2008 \& 2009b).

Calculated composition of the experimental diets:

It could be seen from Table (4) that the percentages of CP were $16.29,15.14,15.69$, and 15.76; OM percentages were 91.60, 90.16, 90.46, and 90.45; and percentages of CF were 11.59, 11.42, 10.88, and 9.94 in $\mathrm{T}_{1}$, $T_{2}, T_{3}$ and $T_{4}$, respectively. These data indicated decreases of CF, EE and ash of $T_{2}$ and $T_{3}$ compared to $T_{2}$ and increased OM, CP, and NFE of $T_{2}$ and $T_{3}$ compared to $T_{2}$. These data are related to the chemical composition of the dietary ingredients (Tables 1 and 2), since banana waste silages were 
Abdelhamid, A. M. et al.

contained lower OM, CP and NFE and higher CF, EE and ash than berseem hay.

Table (4): Chemical composition of the experimental diets.

\begin{tabular}{|c|c|c|c|c|}
\hline \multirow{2}{*}{ Item } & \multicolumn{4}{|c|}{ Dietary treatment } \\
\hline & $T_{1}$ & $T_{2}$ & $\mathbf{T}_{3}$ & $T_{4}$ \\
\hline DM \% & 92.23 & 67.68 & 68.89 & 71.90 \\
\hline \multicolumn{5}{|c|}{ Composition of DM \% } \\
\hline OM & 91.60 & 90.16 & 90.46 & 90.45 \\
\hline $\mathrm{CP}$ & 16.29 & 15.14 & 15.69 & 15.76 \\
\hline $\mathrm{CF}$ & 11.59 & 11.42 & 10.88 & 9.94 \\
\hline $\mathrm{EE}$ & 2.69 & 2.93 & 2.83 & 2.83 \\
\hline NFE & 61.03 & 60.68 & 61.06 & 61.92 \\
\hline Ash & 8.40 & 9.84 & 9.54 & 9.55 \\
\hline
\end{tabular}

\section{Digestibility coefficients:}

It could be seen from Table (5) that the digestibility coefficients of DM increased significantly $(P<0.05)$ in $T_{4}$ and $T_{3}$ compared to $T_{2}$, being $67.10,65.91$ and $63.16 \%$, respectively. Digestibility coefficients of OM increased also significantly $(P<0.05)$ in $T_{4}$ and $T_{3}$ compared to $T_{2}$, being $68.11,66.89$ and $64.10 \%$, respectively. Digestibility coefficients of $\mathrm{CP}, \mathrm{CF}$, $E E$ and NFE increased significantly $(P<0.05)$ in $T_{4}$ and $T_{3}$ compared to $T_{2}$, being $64.58,66.66$ and $62.87 \%$ CP; $56.91,55.33$ and $52.39 \%$ CF; 82.14, 81.53 and $78.28 \% \mathrm{EE}$; and $70.95,68.16$, and $65.03 \%$ NFE, respectively. These data indicated significantly comparable digestibility of all nutrients particularly CF and NFE of $T_{4}$ compared to $T_{1}$. Data indicated that $T_{4}$ contained more digestible DM, OM, CP, CF, EE and NFE being 67.10, 68.11, $64.58,56.91,82.14$ and $70.15 \%$, respectively, compared to $\mathrm{T}_{1}$ (digestibility coefficients of DM, OM, CP, CF, EE and NFE were 70.47, 71.52, 68.44, 53.94, 80.81 and $74.52 \%$, respectively). The results revealed significant differences $(P<0.05)$ among treatments, with no significant $(P>0.05)$ differences between $T_{3}$ and $T_{4}$, except in crude fiber, being 55.33 and 56.91 , respectively. The obtained results agree with those reported by many authors. Choung and Lee (1989) studied the effect of physico-chemical treatment of banana by-products through ammoniation by $3 \%$. They found that DM digestibility increased, being 68 vs. $53.50 \%$ compared with the untreated banana. Mohamed (2001) reported that banana by-products treated with bacteria (Celluomonas cellosea) increased digestion coefficients of DM, OM, CP, EE and CF but decreased NFE compared to untreated. Banana by-products treated with fungus (Phanerochaete chrysoporium) plus bacteria increased the digestion coefficients of DM, OM, CP, EE and CF, but decreased NFE compared to untreated. Banana by-products treated with $4 \%$ urea increased the digestion coefficients of all nutrients than those for the untreated, except NFE which showed insignificant differences.

In addition, Shoukry et al. (1992) found that ensiling banana byproducts after treatment with $3 \%$ urea had resulted in an increase in digestibilities of DM, OM, CP, CF, and NFE while digestion of EE was 
decreased. Hassan et al. (2005) found that silage making decreased CF and cell wall components but increased ash and EE contents. Also, Mohsen et al. (2006) found that silage making decreased CF and cell wall components but increased EE and ash contents. Inoculant increased the apparent digestibility of all nutrients followed by silage treated with urea as compared to untreated control silage. Abd El-Ghani (1999) indicated that the differences between cows fed control and ration contained $15 \%$ banana plant wastes in nutrients digestibility coefficients were significant. Digestion of DM, CP, EE and NFE decreased significantly with increasing the percentage of banana plant in the ration. However, the addition of concentrate to a silage basal diet improved digestibility. In addition, the quality of silage positively and significantly affected both DM and OM digestibility of silage (Abdelhamid and Topps, 1991). Moreover, Abdelhamid et al. (2009a \& b) reported an improved digestibility of $\mathrm{DM}$ and $\mathrm{OM}$ of fungal treated agricultural byproducts.

Table (5): Digestibility coefficients and nutritive value of the tested rations.

\begin{tabular}{|c|c|c|c|c|}
\hline \multirow{2}{*}{ Item } & \multicolumn{4}{|c|}{ Dietary treatments } \\
\hline & $\mathrm{T}_{1}$ & $\mathrm{~T}_{2}$ & $\mathbf{T}_{3}$ & $\mathbf{T}_{4}$ \\
\hline \multicolumn{5}{|c|}{ Digestibility coefficient (\%): } \\
\hline $\mathrm{DM}$ & $70.47^{a} \pm 0.46$ & $63.16^{c} \pm 0.90$ & $65.91^{b} \pm 0.62$ & $67.10^{b} \pm 0.98$ \\
\hline OM & $71.52^{a} \pm 0.47$ & $64.10^{c}+0.91$ & $66.89^{b}+0.63$ & $68.11^{b} \pm 0.99$ \\
\hline $\mathrm{CP}$ & $68.44^{a} \pm 0.75$ & $62.87^{c} \pm 0.89$ & $66.66^{\mathrm{ab}} \pm 0.45$ & $64.58^{\mathrm{bc}} \pm 0.67$ \\
\hline $\mathrm{CF}$ & $53.94^{b c}+0.58$ & $52.39^{c}+0.59$ & $55.33^{b}+0.62$ & $56.91^{\mathrm{a}} \pm 0.59$ \\
\hline EE & $80.81^{b}+0.21$ & $78.28^{c}+0.46$ & $81.53^{\mathrm{ab}}+0.36$ & $82.14^{a}+0.35$ \\
\hline NFE & $74.52^{a}+0.50$ & $65.03^{c} \pm 1.32$ & $68.16^{\mathrm{bc}} \pm 0.82$ & $70.95^{b}+1.26$ \\
\hline \multicolumn{5}{|c|}{ Nutritive value (\%)as fed: } \\
\hline TDN & $62.50^{a}+0.46$ & $40.69^{c}+1.10$ & $43.65^{\mathrm{bc}} \pm 2.36$ & $46.70^{b} \pm 0.85$ \\
\hline DCP & $10.28^{a}+0.11$ & $6.44^{\mathrm{c}}+0.09$ & $7.21^{\mathrm{bc}} \pm 0.41$ & $7.32^{b}+0.20$ \\
\hline \multicolumn{5}{|c|}{ Nutritive value (\%)on DM basis: } \\
\hline TDN & $67.77^{a}+0.59$ & $60.11^{c}+0.97$ & $63.29^{b}+0.98$ & $64.98^{b}+0.65$ \\
\hline DCP & $11.15^{\mathrm{a}} \pm 0.12$ & $9.52^{c} \pm 0.09$ & $10.46^{b} \pm 0.19$ & $10.18^{b}+0.02$ \\
\hline
\end{tabular}

$$
(P<0.05) \text {. }
$$

\section{Nutritive value on DM basis:}

The nutritive value (Table 5) as TDN did not differ significantly $(P>0.05)$ in $T_{3}$ from $T_{4}$, being 63.29 and $64.98 \%$, respectively, but increased significantly $(P<0.05)$ in $T_{3}$ and $T_{4}$ compared to $T_{2}$, being 63.29; 64.98 and $60.11 \%$, respectively and decreased significantly $(P<0.05)$ in $T_{2}, T_{3}$ and $T_{4}$ compared to $T_{1}$, being $60.11,63.29,64.98$ and $67.77 \%$, respectively. Also, the nutritive value as DCP did not differ significantly $(P>0.05)$ in $T_{3}$ than $T_{4}$ $(10.46$ and $10.18 \%)$, but there were significant $(P<0.05)$ increases for $T_{3}$ and $\mathrm{T}_{4}$ compared to $\mathrm{T}_{2}$, being $10.46,10.18$ and $9.52 \%$, respectively. Yet, significant $(P<0.05)$ decreases were found in $T_{2}, T_{3}$ and $T_{4}$ compared to $T_{1}$, being 9.52, 10.46, 10.18 and $11.15 \%$, respectively. The obtained results agree with those of Choung and Lee (1989), who studied the effect of physico-chemical treatment of banana by-products through ammoniation by $3 \%$. They found an improvement of nutritive value of the by-products due to 
the treatment. Mohamed (2001) reported that banana by-products treated with bacteria (Celluomonas cellasea) reflected feeding values expressed as TDN, SV, and DCP which increased significantly than those for untreated. The banana by-products treated with fungus (Phanerochaete chrysoporium) plus bacteria gave feeding values as TDN and SV not significantly differed from those for the untreated, but DCP value was significantly higher than the untreated roughage. The banana by-products treated with $4 \%$ urea reflected feeding values as TDN, SV and DCP higher significantly $(P<0.05)$ than the untreated. Hassan et al. (2005) found that animals fed on banana waste silage with bacteria and banana waste silage with $\mathrm{EM}_{1}$ had significantly higher nutritive value. Mohsen et al. (2006) evaluated the effect of feeding diary cows on banana (Musa acuminate L.) waste silage alone or treated with urea $3 \%$ or inoculant mixed bacteria. Silage making resulted the highest feeding values for banana waste silage bacteria (63.69\% TDN and 9.30\% DCP) and the lowest values for banana waste silage (60.94\% TDN and $8.8 \%$ DCP). However, urea treated or fungal treatment of agricultural by-products led to higher feeding values (TDN, SV and DCP) than the control (Abdelhamid et al., 1991b and 2009b), respectively.

\section{Rumen fermentation:}

Changes in ruminal $\mathrm{pH}$ values with time after feeding presented in Table (6) show that values of $\mathrm{pH}$ were higher before feeding $\left(7.07 \mathrm{~T}_{1}, 7.10\right.$ $T_{2}, 7.10 T_{3}$ and $6.63 T_{4}$ ), and decreased to reach their lowest values almost at 3 hours after feeding $\left(5.73 \mathrm{~T}_{1}, 5.90 \mathrm{~T}_{2}, 6.47 \mathrm{~T}_{3}\right.$ and $\left.5.80 \mathrm{~T}_{4}\right)$. The $4^{\text {th }}$ and $2^{\text {nd }}$ diets $\left(T_{4}\right.$ and $\left.T_{2}\right)$ caused lower pH values than $T_{3}$ at 3 and 6 hours postfeeding, but significantly equal to $T_{1}$ at 3 hours post-feeding. Ammonia- $\mathrm{N}$ concentrations are shown in Table (6). The highest levels of ammonia- $\mathrm{N}$ produced in rumen was for ration containing banana treated with urea $\left(\mathrm{T}_{3}\right)$ at all sampling times, and did rot differ significantly $(P>0.05)$ than $T_{1}$. This may be due to the urea addition to this silage. The increased ruminal $\mathrm{NH}_{3}-\mathrm{N}$ concentrations were related too to the elevated values of ruminal $\mathrm{pH}$ with $\mathrm{T}_{3}$. The ammonia- $\mathrm{N}$ concentrations tended to decreased after six hours of feeding and the lowest concentration was noticed with the $T_{4}\left(14.08 T_{1}, 10.17\right.$ $\mathrm{T}_{2}, 12.51 \mathrm{~T}_{3}$ and $\left.9.38 \mathrm{~T}_{4} \mathrm{mg} / \mathrm{dl}\right)$. The concentration of volatile fatty acids at zero time (before feeding), 3 and 6 hours after feeding are shown in Table (6). There were significant differences among treatments. The highest $(P<$ $0.05)$ level of volatile fatty acids was recorded almost after six hours of feeding (13.25 $\mathrm{T}_{1}, 10.17 \mathrm{~T}_{2}, 16.00 \mathrm{~T}_{3}$ and $\left.12.00 \mathrm{~T}_{4} \mathrm{meq} / \mathrm{dl}\right)$. The trend of changes in ruminal $\mathrm{pH}$ values positively rotated to $\mathrm{NH}_{3}-\mathrm{N}$ and negatively to TVFA's concentrations. But $\mathrm{NH}_{3}-\mathrm{N}$ levels related negatively to TVFA's concentrations. These relations were confirmed before by El-Kady (1997). However, the obtained results agree with those reported by many authors. Jankovsky et al. (1992) reported that when Merino sheep were fed on fresh banana leaves and pelleted Lucerne, concentration of VFA in rumen fluid was increased at $48 \mathrm{hr}$ and then maintained a new value corresponding to that associated with the subsequent diet.

Also, El-Kady (1997) determined $\mathrm{pH}$ values in the rumen fluid of sheep feed banana by-products (Fresh or silage) as the only source of ration. $\mathrm{He}$ found that $\mathrm{pH}$ values were 7.6 vs. 6.4 , respectively, and ammonia- $\mathrm{N}$ was 
11.68 vs. $10.92 \%$ when fresh and silage materials were fed, respectively. Additionally, Abdel-Ghani (1999) found that total VFA's decreased with increasing the percentage of banana plant wastes in the ration. Mohamed (2001) fed ruminants on banana by-products with urea $3 \%$, bacteria and bacteria plus fungi and showed that ruminal $\mathrm{pH}$ ranged from 6.79 (Treated with $3 \%$ urea) to 7.5 (treated with bacteria plus fungi) to 6.69 (Treated with $3 \%$ urea) 3 hrs after feeding and from 7.42 (treated with fungi) to 6.54 (untreated control) $6 \mathrm{hrs}$ after feeding. The minimum $\mathrm{pH}$ values were observed at $3 \mathrm{hrs}$ post feeding tended to increase again at $6 \mathrm{hrs}$. This trend was observed with all banana by-product treatment. These results indicated that there was significantly higher effect for treatment with bacteria plus fungus than those for urea treatment on $\mathrm{pH}$ values, being $7.5 \mathrm{vs.} 6.79$ at zero time. There were in significant differences between the untreated bacteria and fungi treatment. He found also that reminal $\mathrm{NH}_{3}-\mathrm{N}$ ranged from 22.68 to $11.90(\mathrm{mg} / 100 \mathrm{ml})$ before feeding, from 26.97 to $15.40(\mathrm{mg} / 100 \mathrm{ml})$ at $3 \mathrm{hrs}$ after feeding, and from 25.57 to $12.83(\mathrm{mg} / 100 \mathrm{ml}$ ) at $6 \mathrm{hrs}$ after feeding. The maximum $\mathrm{NH}_{3}-\mathrm{N}$ values were observed at $3 \mathrm{hrs}$ post feeding and tended to decrease after wards. The least value for $\mathrm{NH}_{3}-\mathrm{N}$ was obtained for untreated by-products. At $3 \mathrm{hrs}$ after feeding, the highest figures were recorded for biological treatment, being $26.97(\mathrm{mg} / 100 \mathrm{ml})$, and the lowest values were found for urea. Bacteria and bacteria plus fungi treatments produced the highest figures, being 23.80 and $25.57(\mathrm{mg} / 100 \mathrm{ml})$ and the least figures were found for untreated, urea, and acid plus urea treatments, being 14.00, 13.23 and $12.83(\mathrm{mg} / 100 \mathrm{ml})$, respectively, at $6 \mathrm{hrs}$ after feeding.

Kholif et al. (2001) found that ruminal $\mathrm{pH}$ and ammonia nitrogen were not affected by biological treatment. However, TVFA's, total nitrogen, protein nitrogen and true protein nitrogen were significantly $(P<0.05)$ increased by biological treatment compared with control. Moreover, Hassan et al. (2005) reported that silage making significantly increased $(P<0.05)$ total VFA's in $E M_{1}$ banana waste silage than other experimental rations. In addition, Mohsen et al. (2006) registered that total VFA's were significantly $(P<0.05)$ increased in banana waste silage treated with bacteria than other silages. Abdelhamid et al. (2003) concluded that microbial fermentation was not adversely affected by dietary treatments reflecting normal ranges of $\mathrm{pH}$ values, concentrations of VFA's and $\mathrm{NH}_{3}-\mathrm{N}$ in ruminal liquor of calves. Yet, Abdelhamid et al. (2007) registered higher ruminal values of $\mathrm{pH}$, TVFA's and ammonia- $\mathrm{N}$ of lambs fed the control diet than those of animals fed the biological treated mixtures.

From the foregoing results it could be concluded that $\mathrm{EM}_{1}$ as an additive for making silage of banana waste was effective. Ensilage of banana wastes with urea or $\mathrm{EM}_{1}$ reduced the tannins level and $\mathrm{CF}$ content but increased OM, CP, NFE and nutritive value; as well as nutrients digestibility comparing with the banana waste silage without additives, (even comparing with the control, e.g. for CF and EE). So, it is to recommend using banana waste silage with $\mathrm{EM}_{1}$ (or urea) in feeding ruminants. 
Table (6): Effect of treatment and sampling time on ruminal $\mathrm{pH}$, and TVFA's and ammonia concentrations in rumen liquor of growing lambs fed the experimental diets (means $\pm \mathrm{SE}$ ).

\begin{tabular}{|c|c|c|c|c|c|}
\hline \multirow[b]{2}{*}{ Item } & \multirow{2}{*}{$\begin{array}{c}\text { Sampling } \\
\text { time (hr) }\end{array}$} & \multicolumn{4}{|c|}{ Experimental group } \\
\hline & & $T_{1}$ & $\mathrm{~T}_{2}$ & $\mathrm{~T}_{3}$ & $T_{4}$ \\
\hline \multirow[t]{3}{*}{ pH value } & 0 & $7.07 \pm 0.03^{a}$ & $7.10 \pm 0.06^{a}$ & $7.10 \pm 0.06^{a}$ & $6.63 \pm 0.12^{b}$ \\
\hline & 3 & $5.73 \pm 0.13^{b}$ & $5.90 \pm 0.12^{b}$ & $6.47 \pm 0.27^{a}$ & $5.80 \pm 0.10^{b}$ \\
\hline & 6 & $6.30 \pm 0.06^{a}$ & $5.70 \pm 0.17^{b}$ & $6.30 \pm 0.12^{a}$ & $5.80 \pm 0.06^{b}$ \\
\hline \multirow{3}{*}{$\begin{array}{c}\mathrm{NH}_{3}-\mathrm{N} \\
(\mathrm{mg} / 100 \mathrm{ml})\end{array}$} & 0 & $18.77 \pm 0.98^{a}$ & $16.54 \pm 0.99^{a}$ & $17.98 \pm 0.81^{a}$ & $12.91 \pm 1.18^{\mathrm{b}}$ \\
\hline & 3 & $14.08 \pm 0.78$ & $15.64 \pm 0.98$ & $16.42 \pm 0.78$ & $14.86 \pm 1.80$ \\
\hline & 6 & $14.08 \pm 0.35^{a}$ & $10.17 \pm 0.32^{b}$ & $12.51 \pm 0.78^{a}$ & $9.38 \pm 0.40^{b}$ \\
\hline \multirow{3}{*}{$\begin{array}{c}\text { TVFA's } \\
(\mathrm{meq} / 100 \mathrm{ml})\end{array}$} & 0 & $16.67 \pm 0.83^{a}$ & $10.13 \pm 0.63^{b}$ & $12.67 \pm 1.45^{\mathrm{b}}$ & $11.58 \pm 0.87^{b}$ \\
\hline & 3 & $13.03 \pm 0.78^{a}$ & $8.70 \pm 0.15^{\mathrm{b}}$ & $13.82 \pm 0.86^{a}$ & $11.68 \pm 0.72^{a}$ \\
\hline & 6 & $13.25+0.52^{\mathrm{ab}}$ & $10.17+0.73^{b}$ & $16.00+2.00^{a}$ & $12.00+1.32^{\mathrm{ab}}$ \\
\hline
\end{tabular}

a, $b$ and $c$ : Means with different superscripts in the same row are significantly different at $(P<0.05)$.

\section{REFERENCES}

Abd El-Gawad, A.M.; Abd El-Malik, W.H., Allam, Sabbah M. and El-Said, I.M. (1994). Utilization of banana tomato and potato by-products by sheep. Egyptian J. Anim. Prod. Vol. 31, Supplement Issue. Nov.: 215.

Abd El-Ghani, A.A. (1999). Utilization of banana plant wastes by lactating Friesian cows. Egyptian J. Nutrition and Feeds. 2: $29-37$.

Abdelhamid, A.M. (1983). Mykotoxin-Nachweis in Lebens-und Futtermitteln des subtropischen Klimas. In: Kurzfassungen der Vortäge zur 37. Tag. Ges. Emährungsphysiol. Haustiere, Göttingen, 5. Z, Tierphysiol., Tieremährug u Futtermittelkde,, 50: 4-5 (Egyptian Agricultural Bibliography, IX, 1986, 85-100338).

Abdelhamid, A. M. (1988). Utilization From Agro-industrial By-products in Ruminant's Feeding. $1^{\text {st }}$ Nat. Conf. on the Role of the Sci. Res. in Raising Animal Wealth. 2nd Forum: Developing Ruminant's Feed Resources. 25-29 Sept., pp: 119-130. Acad. Sci. Res. Technol., Cairo.

Abdelhamid, A.M. (1991). Farm Animal Husbandry. 1st Ed., Dar Anashr for Universities, Cairo and Alwafaa Bookshop, Mansoura, Egypt, Deposit No. 7136/1990, ISBN: 977-15-0018-X.

Abdelhamid, A.M. (1993a). Decontamination of aflatoxins-contaminated foods by some physical means. J. Egypt. Ger. Soc. Zool., 12(A): 191208.

Abdelhamid, A.M. (1993b). Mycotoxins in local foods and feeds. The $4^{\text {th }}$ Symposium of Food Pollution Assiut Univ., 15 - 16 Nov., pp: $46-57$.

Abdelhamid, A.M. (1995). Quality of feeding stuffs. Forum: Egyptian Animal Wealth, Its Present and Future. 27 March, Agricultural Club, Dokki, 8p.

Abdelhamid, A.M. (2000). Fungi and Mycotoxins. 1st Ed., Dar Anashr for Universities, Cairo, Egypt.

Abdelhamid, A.M. (2003). Harms of Food and Feeding. 2nd Ed., Dar Anashr for Universities, Cairo Egypt, Deposit No. 11828/1999, ISBN: 977-316025-4. 
Abdelhamid, A.M. (2004). Mycotoxins and their relations to human and animal health - How mycotoxins contaminate foods. Forum in Damitte Faculty of Science, 20 April (in Arabic).

Abdelhamid, A.M. (2005). Carcinogens. 1 st Ed., Dar Anashr for Universities, Cairo, Egypt, Deposit No. 1949/2005, ISBN: 977-316-149-8.

Abdelhamid, A.M. (2008). Farm Animal Helath. 1st Ed., Al-Maaref, Alexandria, Egypt, Deposit No. 16593/2008, ISBN: 978-977-03-14838.

Abdelhamid, A.M. (2009a). Thirty years (1978-2008) of mycotoxins research at Faculty of Agriculture, Almansoura University, Egypt. Egyptian J. Nutrition and Feeds, 12(1): $1-14$.

Abdelhamid, A.M. (2009b). The animal's physiological nutrition. 1 1 st Ed., Academic Bookshop, Cairo, Deposit No. 4767/2009, ISBN: 977-281406-4.

Abdelhamid, A.M. and El-Ayoty, S.A. (1988). Feeding sheep on pea byproducts produced during preparation for freez-preservation. Archiv für Tieremährung, 38: $789-797$.

Abdelhamid, A.M. and Saleh, M.R.M. (1996). Are aflatoxin and ochratoxin endemic mycotoxins in Egypt? Proc. Food Borne Contamination and Egyptian's Health Conference, Mansoura Univ., 26 - 27 Nov., pp: 51 59.

Abdelhamid, A.M. and Topps, J.H. (1991). Effect of a dietary concentrate on the digestibility of grass silages. Arch. Anim. Nutr., Berlin, 41: 737 744.

Abdelhamid, A.M.; Abdel-Khalek, A.E.; Mehrez, A.F., Omar, E.A. and Abou El-Hamd, M.A. (2003). Nutritional and physiological studies on Friesian calves fed protected fat and protein diest: 2-Some rumen parameters. Egyptian J. Nutrition and Feeds, 6 (Special Issue): 649 - 662.

Abdelhamid, A.M.; Bassuny, S.M.; Abd El-Aziz, A.A. and Ibrahim, M.Y.S.A. (2009a). Evaluation of biological treatments for agricultural by-products in ruminants feeding. I- Labouratorial study. J. Agric. Sci. Mansoura Univ., 34: 6227 - 6237.

Abdelhamid, A.M.; Bassuny, S.M.; Abd El-Aziz, A.A. and Ibrahim, M.Y.S.A. (2009b). Evaluation of biological treatments for agricultural by-products in ruminants feeding. II- Digestibility study. J. Agric. Sci., Mansoura Univ., 34: $6239-6250$.

Abdelhamid, A.M.; Bassuny, S.M., Abd El-Aziz, A.A. and Ibrahim, M.Y.S.A. (2009c). Evaluation of biological treatments for agricultural by-products in ruminants feeding. III- Growth of lambs. J. Agric. Sci., Mansoura Univ., 34: $6251-6259$.

Abdelhamid, A.M.; El-Mansoury, A.M.; Osman, A.I. and El-Azab, S.M. (1999). Mycotoxins as causative for human food poisoning under Egyptian conditions. J. Agric. Sci., Mansoura Univ., 24: 2751 - 2757.

Abdelhamid, A.M.; Faued. A.M., Ghanem, A.Z. and Helal, H.G. (2006). Studies on biological treatment of salt plants. 1- Feed evaluation by smll ruminants. J. Agric. Sci. Mansoura Univ., 31: 627 - 640. 
Abdelhamid, A.M.; Fayed, A.M., Ghanem, A.Z. and Helal, H.G. (2007). Studies on biological treatment of salt plants. II- Fattening trial. J. Agric. Sci., Mansoura Univ., 32: 151 - 165 (Ovine Technical Articles, engormix. Com., 2007, 12 p.).

Abdelhamid, A.M.; Gabr, A.A. and El-Shinnawy, M.M. (1994). Effect of hydrogen peroxide and urea treatment on chemical composition, cell wass constitutents and in vitro organic matter digestibility of rice straw and maize stover. J. Agric. Sci., Mansoura Univ., 19: 3647 - 3657.

Abdelhamid, A.M.; Nowar, M.S.; Bassuny, S.M. and El-Emam, G.I. (2001). Evaluation of unconventional silage making using plant and animal wastes in feeding ruminants. J. Agric. Sci., Mansoura Univ., 26: 5349 5360.

Abou-Selim, I.A. and Bendary, M.M. (2005). Feed stuffs resources in Egypt. Sources and maximization of its utilization. Proc. $2^{\text {nd }}$ Conf. Anim. Prod. Res. Inst., Sakha, 27 - 29 Sept., $57-67$.

Albert Govt. (2008). Moldy silage: Frequently asked questions. Agriculture and Rural Development, engormix.com.

A.O.A.C. (1980). Official methods of analysis (13는 Ed.). Association of official analytical chemists, Washignton, DC, USA.

A.O.A.C. (1990). Official methods of analysis (15 th $\mathrm{Ed}$.). Association of official analytical chemists, Washignton, DC, USA.

Biomin (2008). New inoculant for wrapped silages. http://www.allaboutfeed net.

Choung, C.C. and Lee, W.S. (1989). Utilization of banana by product as ruminant feed. J. Anim. Sci., 31: $585-592$.

Conway, E.F. (1957). Microdiffusion analysis and volumetric error. Rev. Ed. Lock Wood, London.

Corrier, D.E. (1991). Mycotoxicosis: mechanisms of immunosuppressant. Veterinary Immunology and Immunopathology, 30: 73 - 87.

Cullison, E.F. (1982). Feeds and Feeding. 3 3 rd Ed. Reston Publishing Company, Inc. Virginia, USA.

Dawson, K.A. (1992). Current and future role of yeast cultures in animal production: A review of research over the last six years. In: Supplement to the proceedings of Alltech's $8^{\text {th }}$ Annual symposium. 1: 23.

Diekman, M.A. and Green, M.L. (1992). Mycotoxins and reproduction in domestic livestock. J. Anim. Sci., 70: 1615 - 1627.

Duncan, D.B. (1955). Multiple range and multiple Ftest-Biomtrics - 11: 1.

El-Ashry, M.A., Kholif, A.M., Fadel, M., El-Alamy, H.A., El-Sayed, H.M. and Kholif, S.M. (2003). Effect of biological treatments on chemical composition and in vitro and in vivo digestibilites of poor quality roughages. Egyptian J. Nutr. \& Feeds, 6: 113-126.

El-Barbary, M.I. (2008). Aflatoxin $B_{1}$ induced- changes in protein electrophoretic pattern and DNA in Oreochromis niloticus with special emphasis on the protective effect of rosemary and parsley extracts. American-Eurasian J. Agric. \& Environ. Sci., 4(3): 381 - 390. 
El-Dosyki, A.A.; Moshhour, W., Labeb Ebtsam and Abou-Shak, Fatma (2002). Scientific leaflet on using useful micro-organisms. EM. Effective micro-organisms (in Arabic) Ministry of Agric. and Land Reclamation A.R.C., Central Administration for Agric. Extension. Scientific leaflet No. 755.

El-Kady, R.I. (1997). Utilization of banana wastes by sheep and goats. Ph.D. Thesis, Fac. Agric., Cairo Univ., Egypt.

El-Serafy, A.M. (1991). Efficiency of converting Egyptian clover to milk and meat production in to models of animal. Poultry and fish nutrition. Sakha, Kafr El-Seikh. 26-28 No. pp. 119 (in Arabic).

El-Shanawany, A.A.; Mostafa, M.E. and Barakat, A. (2005). Fungal populations and mycotoxins in silage in Assiut and Sohag governorates in Egypt, with a special reference to characteristic Aspergilli. toxins. Mycopathologia, 159: $281-289$.

Hassan, A.A.; Yacout, M.H.M.; Mohsen, M.K.; Bassiouni, M.I. and Abd El-All, M. (2005). Banana waste (Musa acuminata L.) Silage treated biologically or with urea for Dairy cows feeding. Egyptian J. Nutrition and feeds 8(1) Special Issue: $49-61$.

Herman, T. and Trigo-Stockli, D. (2008). Mycotoxins in feed grains and ingredients. Mycotoxins Technical Articles, engormix. Com., $12 \mathrm{p}$.

IARC (2002). Aflatoxins. IARC Summary \& Evalation, Volume 82, $6 \mathrm{p}$.

Ibrahim, M.A.; Holmann, F.; Hernandez, M. and Camero, A. (2000). Contribution of Erythrina protein banks and rejected bananas for improving cattle production in the humid tropics. Agroforestry systems; 49: 245.

Jankovsky, M., Petru, V. and Hubacek, M. (1992). Volatile acid content in rumen fluid of sheep fed on different diets and during changing of the diets. Zivacisua-Vyroba, 37: 47 - 54. (CAB Abstract publication data).

Kholif, A.M., El-Alamy, H.A.; El-Ashry, M.A., El-Sayed, H.M., Fodel, M. and Kholif, S.M. (2001). Biological treatments of banana wastes lactating Goats Feeding. Egyptian J. Nutrition and feeds (2001) 4(Special Issue): 43.

Kihara, T.; Matsuo, T.; Sakamoto, M.; Yasuda, Y., Yamamoyo, Y. and Tanimura, T. (2000). Effects of prenatal aflatoxin $B_{1}$ exposure on behaviors of rat offspring. Toxicological Sciences, 53: $392-399$.

Meyer, H.; Bronsch, K. and Leibetseder, J. (1980). Supplemente Zu Varlesungen Übungen in der Tierernährung. 5-neu bearbeitete und erweiterte Auflage. Verlag Sprungmann, Hannover.

Ministry of Agriculture and Reclamation (2003). Agricultural Economics. Bull. Central Dept. of Agric. Economics. Cairo, Egypt.

Mohamed, I.M.E. (2001). Effect of mechanical, chemical and/or biological treatment of roughages on ruminal activity. Ph.D. Thesis, Fac. Agric., Cairo Univ., Egypt.

Mohmoud, M.A.M. (2005). Nutritional studies on Farm animals. Ph.D. Thesis, Fac. Agric., Kafr El-Sheikh Univ., Egypt.

Mohsen, M.K.; Bassuni, M.I.; Yacout, M.H. and Mahmoud, M.A.M. (2006). Nutritional studies on the use of banana waste silage in feeding lactating cows. J. Agric. Res. Tanta Univ., 32(3): 2006. 
NRC (1985). Nutrient requirements of sheep. Pp. 54 - $73 . \quad$ National Academy Press. Washington, DC.

Qureshi, M.A.; Brake, J.; Hamilton, P.B., Hagler, Jr. and Nesheim, S. (1998). Dietary exposure of broiler breeders to aflatoxin results in immune dysfunction in progeny chicks. Poult. Sci., 77(6): $812-819$.

Shoukry, M.M.; Ali, H.M., El-Ashry, M.A. and Salman, F.M. (1992). Effect of urea treatment level and ensiling period on the chemical composition nitrogen Fixation and nutritive value of some poor quality roughages. Zagazig J. Agric. Res., 19: 1795 - 1814.

SPSS (2004). Statistical package for the Social Sciences. Release: 13. SPSS INC, Chicago, USA.

Swamy, H.V.L.N. (2009). Mycotoxins- Part 2 Current thoughts on global mycotoxicoses. World Poultry, 25(7): $18-20$.

Taylor-Pickard, J. (2008). How to manage mycotoxins in feed. Feed Tech., 12(3): $23-25$.

Verma, D. (2007). New facts about mycotoxin control - Intensive research in the field of mycotoxin deactivation gives new insights. Mycotoxins Technical Articles, engormix. Com, 4 p.

Viswanathan, R., Kadirvel, R. and Chandrasederson, D. (1989). Nutritive value of banana stalk (Musa converdisia) as a feed for sheep. Animal Feed Science and Technology, 22: 127.

Warner, A.C.I. (1964). Production of volatile fatty acids in the rumen, methods of measurements. Nutr. Abstr. \& Rev., 34: $339-341$.

Woolford, M.K. (2007). Bacterial developments: their implications for silage production and aerobic stability. http://www.engormix.com.

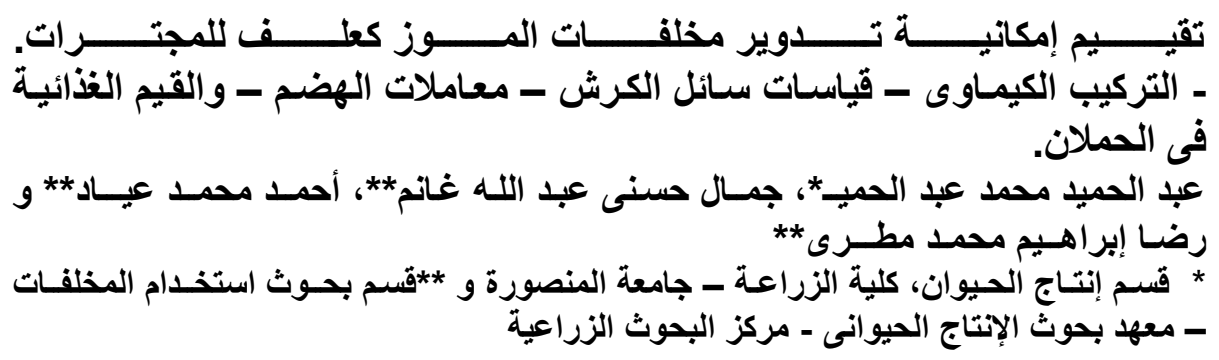

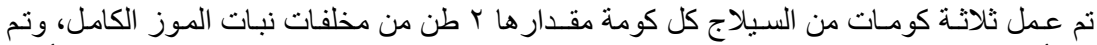

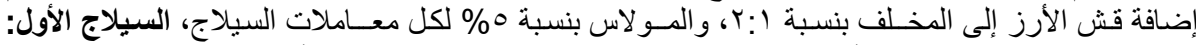

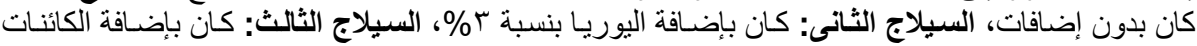

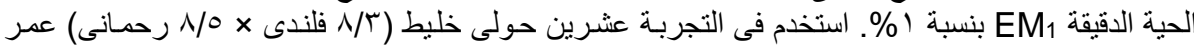

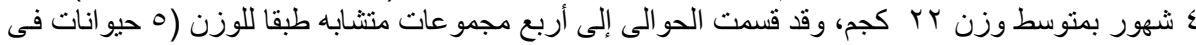

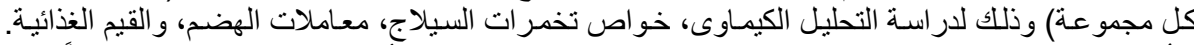

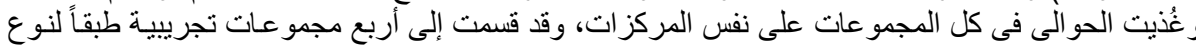

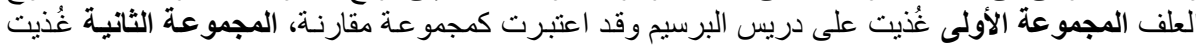

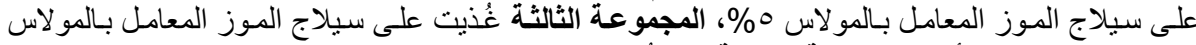

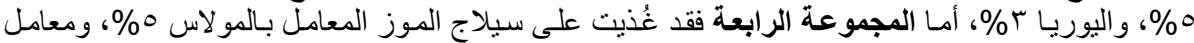

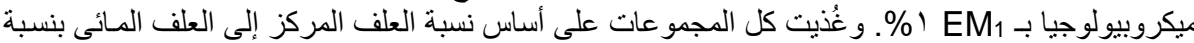

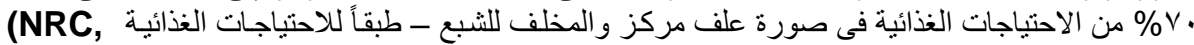


(1985 ويتم التعديل طبقاً للتغير فى وزن الجسم، وقد استمرت فترة التغذيـة لمدة ستة شهور ( • (1 التوماً).

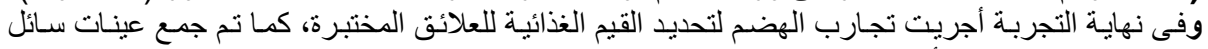

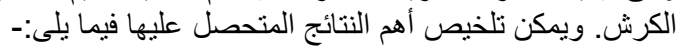

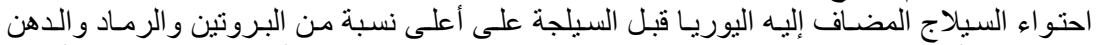

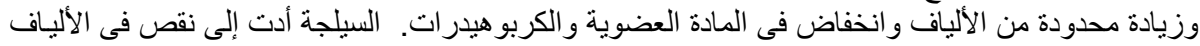

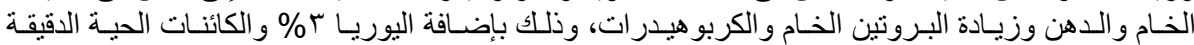
EM1

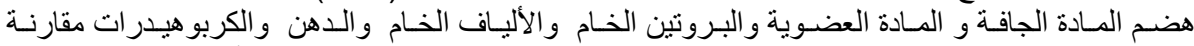

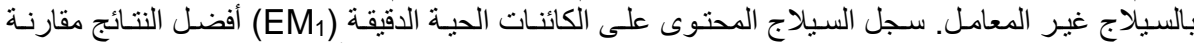

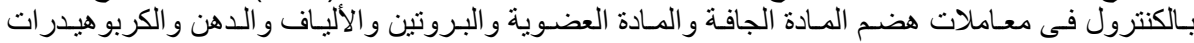

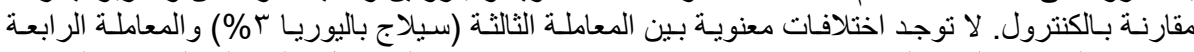

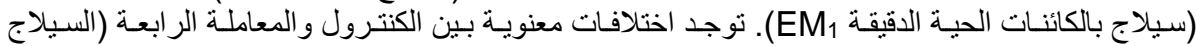

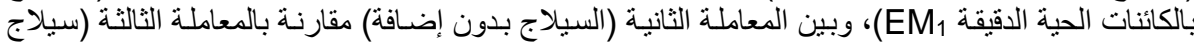

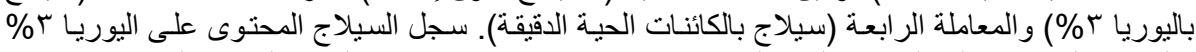

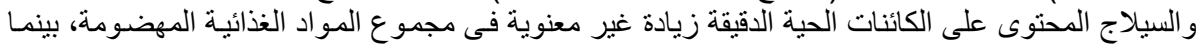

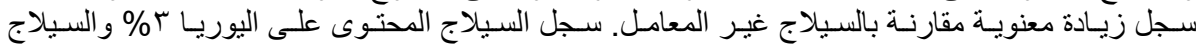

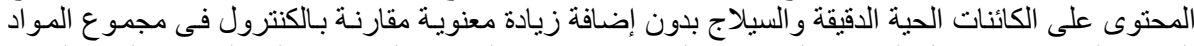

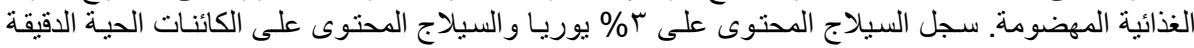

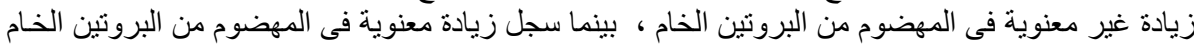

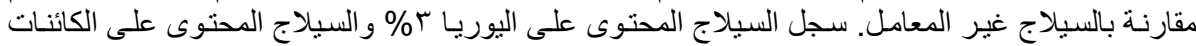

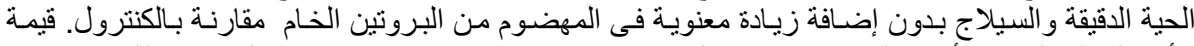

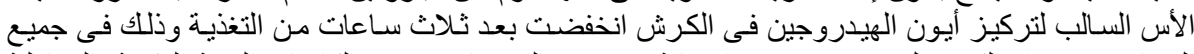

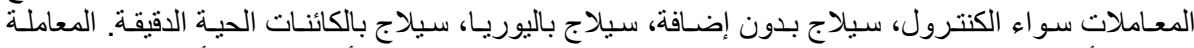

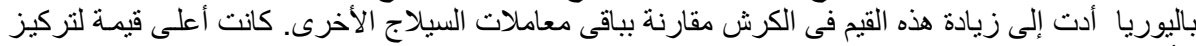

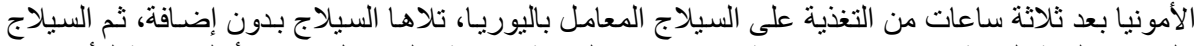

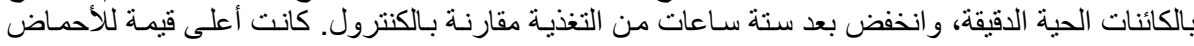

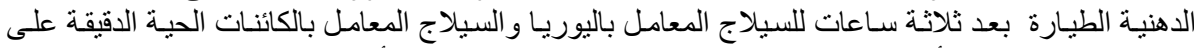

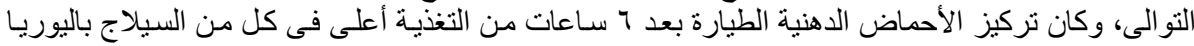

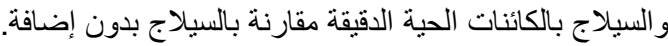

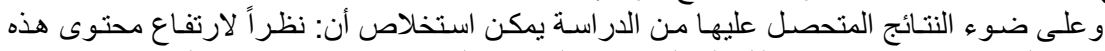

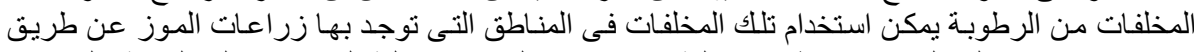

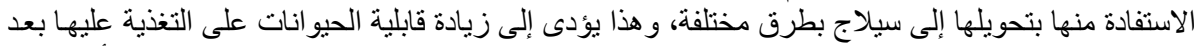

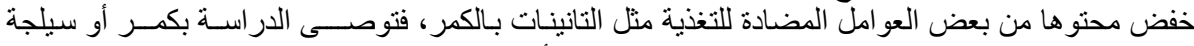

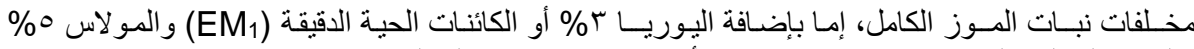

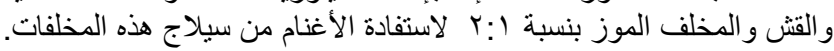

كلية الزراعه - جامعة المنصوره معهد بحوث الانتاج الحيوانى
قام بتحكيم البحث

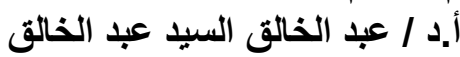
أ.د / بهيزه مصطفى كامل 